\title{
HEARING STATUS OF CHILDREN WITH BEHÇET'S DISEASE: A PROSPECTIVE PRELIMINARY STUDY
}

\author{
BEHÇET HASTALIĞI OLAN ÇOCUKLARIN IŞITME DURUMU: PROSPEKTIF BIR ÖN \\ ÇALIŞMA
}

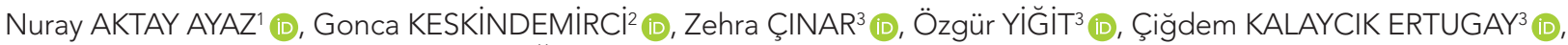 \\ Mustafa ÇAKAN ${ }^{1}$ (D), Şerife Gül KARADAĞ ${ }^{1}$ (D), Esat ALKAYA ${ }^{3}$ (D) \\ ${ }^{1}$ Istanbul University, Istanbul Faculty of Medicine, Department of Pediatrics, Division Pediatric Rhomatology, İstanbul, Turkey \\ ${ }^{2}$ Istanbul University, Istanbul Faculty of Medicine, Department of Pediatrics, Division Social Pediatrics, Istanbul, Turkey \\ ${ }^{3}$ Health Science University Istanbul Education and Research Hospital, Otolaryngology Unit, Istanbul, Turkey
}

ORCID IDs of the authors: N.A.A. 0000-0003-3594-7387; G.K. 0000-0003-1797-2802; Z.Ç. 0000-0002-5027-4750; Ö.Y. 0000-0003-1731-3233; Ç.K.E. 0000-0003-1802-2024; M.Ç. 0000-0002-1034-6406; Ş.G.K. 0000-0002-3232-0055; E.A. 0000-0002-9547-4289

Cite this article as: Aktay Ayaz N, Keskindemirci G, Cinar Z, Yigit O, Kalaycik Ertugay C, Cakan M, et al. Hearing status of children with Behçet's disease: a prospective preliminary study. J Ist Faculty Med 2021;84(4):537-42. doi: 10.26650/IUITFD.2021.837691

\section{ABSTRACT}

Objective: We aimed to evaluate the hearing status of children with Behçet's Disease (BD).

Materials and Method: It is a prospective, cross-sectional, controlled study. Pure-tone audiometry including high-frequencies and distortion product otoacoustic emission (DPOAE) were performed in 15 children with BD and 13 healthy controls.

Results: Although both groups had normal hearing levels, the pure tone average of the study group was higher than the healthy controls. Hearing thresholds at $500 \mathrm{~Hz}$ and $4000 \mathrm{~Hz}$ were statistically significantly higher in children with $\mathrm{BD}$. There was a significant difference in DPOAE levels at $1000 \mathrm{~Hz}$ and $4000 \mathrm{~Hz}$. Children with BD had lower levels at these frequencies.

Conclusion: In spite of the statistical differences in pure tone audiometry between the two groups, the delta was about $5 \mathrm{~dB}$, which might not have clinical importance. However, this is the first study in children, and further studies are required.

Keywords: Hearing evaluation, Behçet's disease, otoacoustic emission, children

\section{ÖZET}

Amaç: Behçet Hastalığı (BH) olan çocukların işitme durumunu araştırmayı amaçladık.

Gereç ve Yöntem: Bu çalışma prospektif, kesitsel, kontrollü bir çalışmadır. On beş BH olan ve 13 sağlıklı çocuğa yüksek frekansları içeren saf ses odyometrisi ve distorsiyon ürünü otoakustik emisyon (DPOAE) uygulanmıştır.

Bulgular: Her iki grup da normal işitme seviyelerine sahip olmasına rağmen, çalışma grubunun saf ses ortalaması sağlıklı kontrollerden daha yüksekti. $500 \mathrm{~Hz}$ ve $4000 \mathrm{~Hz}$ 'de işitme eşikleri $\mathrm{BH}^{\prime}$ li çocuklarda istatistiksel olarak anlamlı derecede daha yüksekti. $1000 \mathrm{~Hz}$ ve 4000 Hz'de DPOAE seviyelerinde önemli fark vardı. BH olan çocuklar bu frekanslarda daha düşük seviyelere sahipti.

Sonuç: İki grup arasındaki saf ses odyometrisindeki istatistiksel farklılıklara rağmen, delta yaklaşık $5 \mathrm{~dB}$ idi ve bunun klinik önemi olmayabilir. Ancak bu çocuklarda yapılan ilk çalışmadır ve daha fazla çalışmaya ihtiyaç vardır.

Anahtar Kelimeler: işitme değerlendirmesi, Behçet hastalığı, otoakustik emisyon, çocuklar

Corresponding author/iletişim kurulacak yazar: ckalaycik@gmail.com

Submitted/Başvuru: 08.12.2020 • Revision Requested/Revizyon Talebi: 08.03.2021 •

Last Revision Received/Son Revizyon: 16.03.2021 • Accepted/Kabul: 08.04.2021 • Published Online/Online Yayın: 13.09.2021 


\section{INTRODUCTION}

Behçet's disease (BD) is a chronic multisystemic vasculitis and defined by Hulusi Behcet in 1937 (1). The onset of $\mathrm{BD}$ is usually in the $2^{\text {nd }}$ decade of life, but although rare, manifestations may start during childhood (2). Although the clinical features may trace each other, the diagnosis of pediatric BD is a challenge. There is limited data about the course of BD in children. The main clinical features are mucocutaneous and ophthalmological lesions. However, vascular, pulmonary, gastrointestinal, musculoskeletal, and neurological involvement might also be noted during the course of the disease (3). Since it is a heterogenous disease with diverse organ involvement, audiological impact may participate the disease course. The incidence of hearing impairment was reported at between 12 to $80 \%$ in several adult studies (4-7). However, there is only one case report presenting a 15-year-old boy with BD and audiovestibular symptoms in the literature (8). According to our knowledge, there are no studies showing the status of hearing thresholds in children with BD who do not have audiovestibular symptoms. In this preliminary study, the objective was to evaluate the hearing functions of children with BD by using high frequency pure tone audiometry (PTA) and distortion product otoacoustic emmisions (DPOAE) and to compare these results with healthy controls.

\section{METHODS}

\section{Ethical considerations}

The current study protocol proceeded in accordance with the ethical standards in the Declaration of Helsinki 1964 and were approved by the local ethical committee (Date/No: 2017/1066). The informed consent of the parents and/or children was obtained.

\section{Participants}

In this prospective, cross-sectional, controlled study, 15 consecutive children diagnosed with Behçet's disease at a tertiary pediatric rheumatology center and 13 healthy controls were enrolled into the study. The diagnosis of $\mathrm{BD}$ was done according to the classification criteria of the International Study Group for BD (9).

\section{Main outcome measures}

Both patient and control groups were evaluated for hearing functions at the otorhinolaryngology unit of the Health Science University Istanbul Training and Research Hospital. The medical records of the patients were reviewed, and socio-demographic characteristics and clinical and laboratory findings were noted. The diagnosis age of all patients was under 18 years, and all were under colchicine treatment. HLA-B51 positivity was checked in all patients.

A clear past history regarding the ear infection, usage of ototoxic medication, trauma, and any other accompany- ing systemic disease that may affect hearing thresholds was taken from all participants. Additionally, a detailed clinical and audiological evaluation was performed by an otorhinolaryngologist. A high-frequency PTA and DPOAE were performed at the otorhinolaryngology department in the Health Science University Istanbul Training and Research Hospital. These tests were performed in a soundproof room. We performed a high frequency PTA using an AC40 Diagnostic Audiometer (Interacoustic Company, Denmark). The measured frequencies of routine PTA include 250, 500, 1000, 2000, and $4000 \mathrm{~Hz}$, and high frequency PTA include 8000, 10000, 12500, and $16000 \mathrm{~Hz}$. All these frequencies were evaluated in each patient. We calculated the PTA average by using hearing thresholds between 500 and $2000 \mathrm{~Hz}$. The hearing level lower than $25 \mathrm{~dB}$ in each of these frequencies was defined as normal hearing. Otoacoustic emission detects the outer hair cell function via detection of the reaction generated by the cochlea across to sound signals. It can be used to differentiate the hearing loss type and predict cochlear sensitivity by early detection of the cochlear damage. DPOAEs were measured at frequencies of 1000, 1400, 2000, 2800, and $4000 \mathrm{~Hz}$ using Otodynamics ILO288 Echoport equipment (Otodynamics Ltd., Hateld, UK). The ratio of a signal to the noise floor was defined as signal-to-noise ratio (SNR). The high SNR ratio indicates a high number of transmitted signals. This condition supports the DPOAE reliability. Also, the high SNR was shown for high DPOAE reliability.

\section{Statistical analysis}

The statistical analysis was performed using the SPSS22.0 program. In the evaluation of the data, a descriptive statistical method was used for mean, standard deviation, median, lowest, highest, frequency, and ratio values. The distribution of the variables was measured by the Kolmogorov Simirnov test. The Mann-Whitney U test was used in the analysis of quantitative independent data, and a Chi-square test was used in the analysis of qualitative independent data.

\section{RESULTS}

Fifteen children (30 ears) with BD (4 female and 11 male) and 13 healthy controls (26 ears) (5 female and 8 male) were enrolled in this study. The mean age of the children with BD and control group were $15.60 \pm 1.92$ years and $13.92 \pm 2.56$ years, respectively. The age and sex distributions were similar in both groups. The mean age of the onset of the disease was $10.9 \pm 3.01$ years, and the mean age at diagnosis was $12.3 \pm 2.7$ years. The mean duration of the disease was $4.6 \pm 2.6$ years. All patients were under colchicine therapy. Nine (\%60) of the patients had HLA B51 positivity. The clinical characteristics and demographic data of the patients are shown in Table 1. None of the children with BD had neurologic involvement. One of 
Table 1: Demographic and clinical features of children with Behçet's disease

\begin{tabular}{lcc}
\hline & $\begin{array}{c}\text { Number of } \\
\text { patients }\end{array}$ & $\%$ \\
Consanguinity & 6 & 40 \\
Family history of Behçet's disease & 4 & 26.6 \\
Oral aphthosis and ulcers & 15 & 100 \\
Genital ulcers & 10 & 66.6 \\
Ocular lesions & 5 & 33.3 \\
Vascular lesions & 2 & 13.3 \\
Skin lesions & 12 & 80 \\
Pathergy & 7 & 46.6 \\
Arthritis & 2 & 13.3 \\
\hline
\end{tabular}

the patients was using azathioprine, one was using azathioprine and prednisolone, and another was using azathioprine and warfarin sodium (because of deep venous thrombosis in the lower extremity) at the time of the study.

\section{Audiologic data}

The mean PTA values were in the normal hearing range in both groups whereas the patient group had higher values which were statistically significant $(p=0.028)$. Hearing thresholds at $250 \mathrm{~Hz}, 1000 \mathrm{~Hz}, 2000 \mathrm{~Hz}, 8000 \mathrm{~Hz}, 10000$ $\mathrm{Hz}, 12500 \mathrm{~Hz}$, and $16000 \mathrm{~Hz}$ were in the normal range in both groups. Although within normal levels, hearing thresholds at $500 \mathrm{~Hz}$ and $4000 \mathrm{~Hz}$ were statistically significantly higher in children with $\mathrm{BD},(\mathrm{p}=0.037$ and 0.031 respectively) (Table 2). DPOAE values at frequencies of $1400 \mathrm{~Hz}, 2000 \mathrm{~Hz}$, and $2800 \mathrm{~Hz}$ were similar between the patient and control groups. However, patients had statistically significantly lower levels at 1000 and $4000 \mathrm{~Hz}$ in DPOAE than the healthy controls ( $p=0.040$ and 0.028 respectively) (Table 3). SNR evaluations in both groups were similar.

\section{DISCUSSION}

In this preliminary study, we evaluated the hearing status of children with BD by using both objective and subjective audiological tests to detect early cochlear involvement. We found higher thresholds at 500 and $4000 \mathrm{~Hz}$ in PTA, despite being normal levels in both patient and control group, and also lower levels at the frequencies of 1000 and $4000 \mathrm{~Hz}$ in the DPOAE test in children with $B D$. Although these differences were statistically significant, the delta of $5 \mathrm{~dB}$ reported in this study as "statistically significant" and the lower levels at 2 frequencies of DPOAE testing might be meaningless in clinical practice. This is because the standards of most experts are not outside the range of test-retest variability; for instance, the test-retest reliability of an audiogram is $5 \mathrm{~dB}$.

$\mathrm{BD}$ is a chronic disease with multiple organ-specific symptoms. It is most commonly seen in the Mediterranean region, the Middle East, and the Far East (the Silk Road). The prevalence was reported at $42 / 10000$ in a study conducted in Istanbul, the largest cosmopolitan city in

Tablo 2: Pure Tone Average values including high frequencies of control group and Behçet's disease (BD)

\begin{tabular}{|c|c|c|c|c|c|c|}
\hline & & \multicolumn{2}{|c|}{$B D$} & \multicolumn{2}{|c|}{ Control group } & \multirow[b]{2}{*}{$p$} \\
\hline & & Mean $( \pm S D) / n$ & Median & Mean $( \pm S D)$ & Median & \\
\hline Age & & $15.6 \pm 1.92$ & 16.00 & $13.9 \pm 2.56$ & 14.00 & $0.094^{\mathrm{m}}$ \\
\hline \multirow[t]{2}{*}{ Sex } & Girl & \multicolumn{2}{|c|}{$n=4(26.7 \%)$} & \multicolumn{2}{|c|}{$n=8(61.5 \%)$} & $0.063^{\times 2}$ \\
\hline & Boy & \multicolumn{2}{|c|}{$\mathrm{n}=11(73.3 \%)$} & \multicolumn{2}{|c|}{$n=5(38.5 \%)$} & \\
\hline PTA & & $9.17 \pm 2.86$ & 9.00 & $6.88 \pm 3.18$ & 6.00 & $0.028^{m}$ \\
\hline $250 \mathrm{~Hz}$ & & $12.17 \pm 3.26$ & 12.50 & $11.77 \pm 5.79$ & 14.00 & $0.098^{m}$ \\
\hline $500 \mathrm{~Hz}$ & & $11.50 \pm 3.25$ & 10.00 & $8.92 \pm 3.12$ & 10.00 & $0.037^{m}$ \\
\hline $1000 \mathrm{~Hz}$ & & $8.67 \pm 3.39$ & 7.50 & $7.69 \pm 2.75$ & 9.00 & $0.425^{\mathrm{m}}$ \\
\hline $2000 \mathrm{~Hz}$ & & $7.33 \pm 3.59$ & 5.00 & $6.00 \pm 5.87$ & 5.00 & $0.148^{m}$ \\
\hline $4000 \mathrm{~Hz}$ & & $9.83 \pm 5.04$ & 10.00 & $5.73 \pm 6.44$ & 6.00 & $0.031^{m}$ \\
\hline $8000 \mathrm{~Hz}$ & & $5.33 \pm 4.62$ & 5.00 & $7.88 \pm 6.99$ & 7.00 & $0.429^{m}$ \\
\hline $10000 \mathrm{~Hz}$ & & $3.83 \pm 6.19$ & 2.50 & $4.31 \pm 5.37$ & 5.00 & $0.674^{\mathrm{m}}$ \\
\hline $12500 \mathrm{~Hz}$ & & $2.83 \pm 8.01$ & 2.50 & $5.62 \pm 6.42$ & 2.50 & $0.226^{\mathrm{m}}$ \\
\hline $16000 \mathrm{~Hz}$ & & $4.70 \pm 7.33$ & 5.00 & $4.96 \pm 5.23$ & 2.50 & $0.907 \mathrm{~m}$ \\
\hline
\end{tabular}

$\mathrm{m}$ : Mann whitney u test $\times 2$ : chi square test 
Table 3: DPOAE and SNR levels of control group and Behçet's disease

\begin{tabular}{lccccc}
\hline & \multicolumn{2}{c}{ Behçet's disease } & \multicolumn{2}{c}{ Control group } & \\
& Mean & Median & Mean & Median & p \\
DP1000 Hz & $2.58 \pm 6.97$ & 3.45 & $7.58 \pm 5.93$ & 8.90 & $\mathbf{0 . 0 4 0}$ \\
DP1400 Hz & $6.14 \pm 8.61$ & 6.70 & $7.7 \pm 7.84$ & 7.15 & 0.764 \\
DP2000 Hz & $2.60 \pm 9.44$ & 4.10 & $5.60 \pm 6.70$ & 5.30 & 0.661 \\
DP2800 Hz & $-1.14 \pm 11.21$ & 0.90 & $1.18 \pm 12.44$ & 3.50 & 0.300 \\
DP4000 Hz & $-0.55 \pm 12.16$ & 1.40 & $8.62 \pm 5.25$ & 7.30 & $\mathbf{0 . 0 2 8}$ \\
SNR1000 Hz & $4.59 \pm 9.16$ & 5.60 & $8.90 \pm 7.54$ & 8.00 & 0.112 \\
SNR1400 Hz & $10.75 \pm 10.49$ & 15.00 & $13.16 \pm 8.69$ & 9.80 & 0.908 \\
SNR2000 zz & $9.32 \pm 11.72$ & 11.40 & $10.50 \pm 10.05$ & 11.05 & 0.908 \\
SNR2800 Hz & $2.32 \pm 10.90$ & 10.35 & $7.03 \pm 13.27$ & 9.70 & 0.836 \\
SNR4000 Hz & $8.38 \pm 12.58$ & 10.35 & $14.88 \pm 7.54$ & 11.25 & 0.345 \\
\hline
\end{tabular}

Turkey (10). The disease often begins early in childhood but may not be diagnosed for many years $(11,12)$. There are numerous studies comparing adult and pediatric patients with BD regarding demographics, clinical features, and course of the disease $(13,14)$. Several studies have evaluated the hearing impairment in adults with $B D$, but there is no reported data concerning the audio-vestibular involvement in pediatric patients with BD. Because of this deficiency in past literature, we evaluated the hearing function in children with BD in the present study which is the first study about this issue.

The reports evaluating the inner ear involvement in adults with $\mathrm{BD}$ are contradictory. Soylu et al. observed hearing loss in 20 of 72 adults with BD at frequencies of $0.25,0.5$, 2 , and $4 \mathrm{kHz}$ while Sonbay et al. reported $23 \%$ of sensorineural hearing loss $(4,5)$. They pointed out that the most significant loss was at the 4 and $8 \mathrm{kHz}$ frequencies. The authors usually used a standard PTA between the frequencies of 250 and $8000 \mathrm{~Hz}$ in order to evaluate audio-vestibular involvement, and some of them determined a down slope at high frequencies (15). According to these data, recent studies investigated higher frequencies up to $16000 \mathrm{~Hz}$ and suggested that the first affected hearing thresholds are usually higher frequencies. Bakhshaee et al. performed a high frequency audiometry (up to 12000 $\mathrm{Hz}$ ) in 27 patients with $\mathrm{BD}$ and showed that $60 \%$ of their cases had hearing loss at high frequencies (16). Süslü et al. investigated frequencies up to $16000 \mathrm{~Hz}$, finding higher hearing thresholds at frequencies of 250, 1000, 2000, 4000, and $8000 \mathrm{~Hz}$ in patients with $\mathrm{BD}$ in comparison to normal subjects although all subjects had normal hearing levels at these frequencies ( $<20 \mathrm{~dB})(7)$. Based on these reports, we also measured high frequencies (measured 9 consecutive frequencies between 250 and $16000 \mathrm{~Hz}$ ) by a detailed PTA. Similar with Süslü et al., all of our patients had normal hearing levels at all frequencies, but inconsistent with this study, we observed statistically significant differences at frequencies of 500 and $4000 \mathrm{~Hz}$ between the patient group and the healthy controls. Moreover, although the hearing levels were in normal limits, we found higher mean PTA thresholds in children with BD. We did not determine hearing impairment in contrast to the previous adult studies. Furthermore, our findings do not support the theory that hearing loss begins firstly at high frequencies in BD. The reason for this may be due to the younger age, shorter duration of disease in our patients in comparison to adult studies, and also the small number of patients in the present study. The inconsistency our results with previous studies showing higher ratios of hearing loss can be explained by the low ages of the patients in the present study. Several reports detecting a relationship between hearing loss and age support this hypothesis $(5,15)$.

There are many studies measuring the auditory status of patients with BD by using PTA whereas some authors have used DPOAEs in auditory evaluation. Sonbay et al. reported significantly lower responses of DPOAEs at all frequencies in BD patients in comparison to healthy subjects (4). Dağlı et al. also found similar results and noted that the DPOAE findings were not correlated with the disease course (17). In the present study, we found that DPOAE responses in only frequencies of $1000 \mathrm{~Hz}$ and $4000 \mathrm{~Hz}$ were lower in children with $\mathrm{BD}$ in comparison to the controls. However, this difference between two groups did not reach statistical significance in the other measured frequencies, and the reason might be the small number of patients of the study group. We know that a normal DPOAE indicates the normal functioning of outer hair cells of cochlea. Based on this fact, our findings may be a sign of weaker outer hair cell motility in pediatric patients with BD. However, the number of patients in the present study was small, and therefore, further studies with larger groups should be performed to verify 
this theory. According to the study of Süslü et al., it was demonstrated that the outer hair cells of patients with BD had less physiological motility (7). This condition was attributed to SNR values that were much lower in comparison to the control group in patients with BD. They underlined that decreased DPOAE responses with normal hearing thresholds in BD could be suggested as one of the early signs of subclinical cochlear involvement. Kemal et al. compared patients with $\mathrm{BD}$ and healthy subjects in terms of transient evoked otoacoustic emission (TEOAE) values and revealed that the difference in SNR between the two groups was significant at $4 \mathrm{kHz}(6)$. They suggested that it is an indicator of cochlear involvement with reproducibility parameters together. In our study, there was no statistically significant difference between two groups in terms of SNR $1000 \mathrm{~Hz}$, SNR $1400 \mathrm{~Hz}$, SNR $2000 \mathrm{~Hz}$, SNR $2800 \mathrm{~Hz}$, and SNR $4000 \mathrm{~Hz}$ values ( $p>0.05$ ).

Sensorineural hearing loss in autoimmune diseases is thought to be originated from vasculitic mechanisms. In different autoimmune diseases, different regions of cochlea were observed to be affected at varying degrees. Hearing loss in $\mathrm{BD}$ is also associated with vasculature due to perivascular immunocytic infiltration (7). Three of our patients were using azathioprine and/or warfarin sodium and/or prednisolone. In the literature, there is no data showing the effect of these drugs on hearing functions. All patients with BD in this study were under colchicine treatment. Keskindemirci et al. evaluated the hearing function of children with Familial Mediterranean Fever (FMF) that were using colchicine at cumulative doses of $1.5 \pm 14 \mathrm{mg}$ and found no hearing loss (18). Therefore, weaker outer hair cell motility may not be related to these medications.

We measured the hearing levels by both a detailed PTA including high frequencies and DPOAE. Although we found higher mean PTA values and higher thresholds at specifically two frequencies, this difference might not be clinically significant. As vasculitic mechanisms are the major etiopathogenesis of $\mathrm{BD}$, the involvement of cochlear blood vessels may induce cochlear pathology and progress to hearing loss.

The small number and normal hearing levels of children with $B D$ are the most significant limitations of our study. Another limitation is that we did not make a speech discrimination test, and therefore, we could not use a standardized reporting format while evaluating our data. This study may be accepted as a pilot study showing the necessity of evaluation of the cochlear function in children with $\mathrm{BD}$ at a larger cohort.

\section{CONCLUSION}

We found a statistically significant difference in the audiologic tests of the diseased group in comparison to the control group. However, all subjects had normal limits of hearing levels and the $\sim 5 \mathrm{~dB}$ difference may not be clinically important. The data of our study may be available as a baseline hearing status of children with $\mathrm{BD}$. Therefore, this is the preliminary study on this issue, and future studies with larger groups should be performed in order to verify our results.

\section{MAIN POINTS}

- In this prospective, cross-sectional, controlled study the hearing status of 15 children with Behçet's Disease and 13 healthy controls were evaluated.

- Although both groups had normal hearing levels, pure tone average of the study group was statistically significantly higher than the control group. However the $\sim 5 \mathrm{~dB}$ difference may not be clinically important.

- This is the preliminary study about this issue, and future multi-center studies with larger subjects should be performed.

Ethics Committee Approval: This study was approved from local ethics committee (Date/No: 2017/1066).

Informed Consent: Written consent was obtained from the participants.

Peer Review: Externally peer-reviewed.

Author Contributions: Conception/Design of Study- N.A.A., G.K., Z.Ç., Ö.Y., Ç.K.E., M.Ç., Ş.G.K., E.A.; Data AcquisitionN.A.A., G.K., Z.Ç., Ö.Y., Ç.K.E., M.Ç., Ş.G.K., E.A.; Data Analysis/Interpretation- N.A.A., G.K., Z.Ç., Ö.Y., Ç.K.E., M.Ç., Ş.G.K., E.A.; Drafting Manuscript- N.A.A., G.K., Z.Ç., Ö.Y., Ç.K.E., M.Ç., S..G.K., E.A.; Critical Revision of Manuscript- N.A.A., G.K., Z.Ç., Ö.Y., Ç.K.E., M.Ç., Ş.G.K., E.A.; Final Approval and Accountability- N.A.A., G.K., Z.Ç., Ö.Y., Ç.K.E., M.Ç., Ş.G.K., E.A.

Conflict of Interest: Authors declared no conflict of interest.

Financial Disclosure: Authors declared no financial support.

Etik Komite Onayı: Bu çalışma için etik komite onayı yerel etik komiteden alınmışıtır (Date/No: 2017/1066).

Bilgilendirilmiş Onam: Katılımcılardan bilgilendirilmiş onam alınmıştır.

Hakem Değerlendirmesi: Dış bağımsız.

Yazar Katkıları: Çalışma Konsepti/Tasarım- N.A.A., G.K., Z.Ç., Ö.Y., Ç.K.E., M.Ç., S.G.K., E.A.; Veri Toplama- N.A.A., G.K., Z.Ç., Ö.Y., Ç.K.E., M.Ç., S..G.K., E.A.; Veri Analizi/Yorumlama- N.A.A., G.K., Z.Ç., Ö.Y., Ç.K.E., M.Ç., Ş.G.K., E.A.; Yazı Taslağı- N.A.A., G.K., Z.Ç., Ö.Y., Ç.K.E., M.Ç., Ş.G.K., E.A.; İçeriğin Eleştirel İncelemesi- N.A.A., G.K., Z.Ç., Ö.Y., C..K.E., M.Ç., S..G.K., E.A.; Son Onay ve Sorumluluk- N.A.A., G.K., Z.Ç., Ö.Y., Ç.K.E., M.Ç., Ş.G.K., E.A.

Çıkar Çatışması: Yazarlar çıkar çatışması beyan etmemişlerdir.

Finansal Destek: Yazarlar finansal destek beyan etmemişlerdir. 


\section{REFERENCES}

1. Behcet H. Uber rezideivierende, aphtose, durch ein virüs veursachte Geschure am Mund, Am Auge und an den Genitalien. Dermatol Wachenschr 1937;105:152-7.

2. Karincaoglu Y, Borlu M, Toker SC, Akman A, Onder M, Gunasti $S$, et al. Demographic and clinical properties of juvenile-onset Behçet's disease: A controlled multicenter study. J Am Acad Dermatol 2008;58(4):579-84. [CrossRef]

3. Sungur GK, Hazirolan D, Yalvac I, Ozer PA, Yuksel D, Vural ET, et al. Clinical and demographic evaluation of Behcet disease among different paediatric age groups. $\mathrm{Br} \mathrm{J}$ Ophthalmol 2009;93(1):83-7. [CrossRef]

4. Sonbay ND, Saka C, Tatlican S, Vuralkan E, Aygener N, Eren $C$, et al. Audiological evaluation in patients with Behçet's disease. J Laryngol Otol 2014;128(8):694-7. [CrossRef]

5. Soylu L, Aydoğan B, Soylu M, Ozsahinoğlu C. Hearing loss in Behçet's disease. Ann Otol Rhinol Laryngol 1995; 104(11):864-7. [CrossRef]

6. Kemal O, Anadolu Y, Boyvat A, Tatarağası A. Behçet disease as a cause of hearing loss: A prospective, placebo-controlled study of 29 patients. Ear Nose Throat J 2013;92(3):112-20. [CrossRef]

7. Süslü $A E$, Polat $M$, Köybaşi $S$, Biçer $Y O$, Funda $Y O$, Parlak $\mathrm{AH}$. Inner ear involvement in Behçet's disease. Auris Nasus Larynx 2010;37(3):286-90. [CrossRef]

8. Marsili M, Marzetti V, Lucantoni M, Lapergola G, Guttarno $\mathrm{M}$, Chiarelli $F$, et al. Autoimmune sensorineural hearing loss as presenting manifestation of paediatric Behçet disease responding to adalimumab: a case report. Ital J Pediatr 2016;42(1):81. [CrossRef]

9. International Study Group for Behcet's Disease. Criteria for diagnosis of Behcet's disease. Lancet 1990;335(8697):107880. [CrossRef]
10. Azizlerli G, Köse AA, Sarica R,Gül A, Tutkun IT, Kulaç M, et al. Prevalence of Behçet's disease in Istanbul, Turkey. Int J Dermatol 2003;42(10):803-6. [CrossRef]

11. Gurler A, Boyvat A, Tursen U. Clinical manifestations of Behcet's disease: an analysis of 2147 patients. Yonsei Med J 1997;38(6):423-7. [CrossRef]

12. Krause I, Uziel Y, Guedj D, Mukamel M, Harel L, Molad Y, et al. Childhood Behcet's disease: clinical features and comparison with adult-onset disease. Rheumatology (Oxford) 1999;38(5):457-62. [CrossRef]

13. Sarica R, Azizlerli G, Köse A, Dişçi R, Ovül C, Kural Z. Juvenile Behcet's disease among 1784 Turkish Behcet's patients. Int J Dermatol 1996;35(2):109-11. [CrossRef]

14. Uziel Y, Brik R, Padeh S, Barash J, Mukamel M, Harel L, et al. Juvenile Behcet's disease in Israel: the pediatric rheumatology study group of Israel. Clin Exp Rheumatol 1998;16(4):502-5.

15. AK E, Harputluoglu U, Oghan F, Baykal B. Behçet's disease and hearing loss. Auris Nasus Larynx 2004;31(1):29-33. [CrossRef]

16. Bakhshaee M, Ghasemi MM, Hatef MR, Talebmehr M, Shakeri MT. Hearing loss in Behçet syndrome. Otolaryngol Head Neck Surg 2007;137(3):439-42. [CrossRef]

17. Dagli M, Eryilmaz A, Tanrikulu S, Aydın A, Gönül M, Ulker $G$, et al. Evaluation of cochlear involvement by distortion product otoacoustic emission in Behçet's disease. Auris Nasus Larynx 2008;35(3):333-7. [CrossRef]

18. Keskindemirci G, Ayaz NA, Batıoğlu-Karaaltın A, Dönmez Z, Özgür Y, Aydoğan G, et al. Cochlear functions in children with familial Mediterranean fever: any role of the severity of the disease. Int J Pediatr Otorhinolaryngol 2015;79(9):156670. [CrossRef] 